\title{
EDUCATIONAL VALUES IN ROMANS: LE ROUGE ET LE NOIR/THE RED AND THE BLACK AND THE CHARTREUSE OF PARMA WRITTEN BY STENDHAL
}

\author{
Sulandri Nuryadin \\ Universitas Negeri Jakarta \\ sulandrinuryadin@unj.ac.id
}

\begin{abstract}
This scientific work is a qualitative research content analysis with genetic structural approach. The objective of this research to meet the existing educational values in the novels The Red and the Black and The Charterhouse of Parma. This research began in November 2013 in Jakarta. Data for this research were taken of the novels to discuss as well as books about the life of the writer and French history in the nineteenth century. The analysis is based on the genetic and structural approach on historical data. The results of this research show that there are educational values explicitly and implicitly in novels studied related to social events that took place at the time the novels were written. They appear in the learning-teaching, religion, social and political events. These values can play a relevant role that can influence the behavior of readers. They could be people who put worth reading will; the desire to acquire languages a language like Latin andcuriosity towards a colosal event. The results of this research could motivate university students of French to find the pleasure of reading novels in order to enrich them selves intellectually and culturally.
\end{abstract}

Keywords: Educational values, Romans, Genetic Structurale.

Education is one of the most important events in human life. In general, a child receives the education process first from his mother, then from his father, then from his environment and eventually through formal or non-formal education.Education Contains values. Indonesian values are called "nilai-nilai". Value is the price and appreciation of normative functions as a motivating factor. Values contain hopes, ideals and something mandatory so that they have ideal properties. Educational values exist in all facets of human life and civilization. Educational values are embodied in the attitudes and behaviors of humans. We can not deny that human life is determined by the results of his education.

According to Welek and Warren "literature is a creative activity, a work of art." The literary work is one of the creation of man (authors), which has become the consumption of the reader. The culture of a nation to other nations An author who makes a literary work, the content of his work can not be separated from the experience of life and the situation in wahich he lives.

In the nineteenth century, a novelist named Stendhal wrote two great novels Le Rouge et le Noir and La Chartreuse de Parme, two great literary works have been translated into many languages. Stendhal won a high distinction by his immortalized name on the University of Grenoble III. The University was renamed Stendhal University-Grenoble 3. The decision to take the two novels: Red and Black and Stendhal's Parma Chartreuse as a source of research data is also based on a reality that the author and his literary work have become centers of study in France. 
Although the content of both novels is dominated by themes of love, politics, also shows the theme of education. One sees the aspects of educational values contained in the novels The Red and the Black and the Chartreuse of Parma, as seen from the point of view of the structural genetic life of Stendhal, a writer, linked to social and political events that have Occurred during the life of the author. So this research is done by first explaining the state of life of the author, the intellectual community that influences for his life the socio-economic events that have occurred. All this affects the life of the author, as well as the decisions of the government of his time in the development of this study. The research question posed in this research is How the educational values of the novel The Red and Black and The Charterhouse of Parma from the point of view of the structure of the novel, from the point of view of the social status of Stendhal as an author and point From the world of others, This study is a qualitative study using a method of content analysis (Content Analysis) approaching genetic structuralism.

According to Lucien Goldmann, from the perspective of genetic structuralism, there are three basic characteristics of human behavior, with a note that the analysis is actually true, the determining characteristic of positive studies and the scientific methodology of social life in General, and more particularly the study of cultural creations. This study is a literature search: a library research that has the purpose of examining books / documents that can provide confirmation of the existence of the elements of education in the novel The Red and Black and The Charterhouse of Parma , Works of Stendhal. The main location of the research is in Jakarta for ten months.

This is a qualitative study using the structural genetic approach while the applied research method is a content analysis. The study focused on a repeat / intensive reading of: a. The work of Stendhal is novel The Red and the Black (Le Rouge et le Noir) and The Charterhouse of Parma (La Chartreuse de Parme) b. The data in the form of biographies, history, socio-culture. Documents of the author in the world and the world literature which explains the life of Stendhal and his works.To answer the research questions below, the data from this study are: Words, phrases, sentences and sentences that show the value of education and the data source is; Roman The Red and the Black and The Charterhouse of Parma romance books about the author's biography, socio-cultural events that take place during the life of the author, historical documents that tell the story and Political events during the life of the author of these novels.

The techniques and procedures for collecting data in this qualitative research with the genetic structural approach (based on Lucien Goldman's book Genetics Structuralism) involve the following steps:

1. Collection and reading of intensive data of books / main documents: Roman The red and black, novel La Chartreuse de Parme; Biography of the author of the novel: Stendhal, Document literary critic, books of literary sociology, books concerning the structural approach of genetic research; Stendhal and the Problems of personality prepared by Geoges Blin, Readings of Stendhal The Red and the Black composed by Xavier Boudenet. Stendhal The Charterhouse of Parma written by ellipses, analyzes and Stendhal Lucien Leuwen writes Ellipes de Reflexions, French book history of the nineteenth century.

2. Data collection is based on a research focus, research questions.

3. Analysis of data based on aspects of the genetic structural approach

4. Interpretation of research results

5. Checking the validity of search data

6 . The results of the research 
A. The corpus contains intellectual educational values in the novel The Red and the Black No/charactersoutlined/contexts

1/ Mr. de Renal in the same. De Rênal "I absolutely want to take home, Sorel, son of the sawyer of planches $<\ldots>$ he will watch the children <...> It is a young priest, so good, good Latinist and that will make progress to the children/ In the garden of Monsieur de Rênal

2/ Narrator "Father Sorel saw Julien five or six feet higher, straddling one of the rooms of the roof, instead of watching attentively the action of the whole mechanism, Julien read, Which the young man gave to his book, far more than the sound of the saw, prevented him from hearing the terrible voice of his father. A violent blow caused the book which Julien held to be stolen in the stream. He looks sadly at the brook where his book had fallen; It was that of all he loved most, the Memorial of St. Helena"/ in the sawmill of the Sorel family.

3/ Monsieur de Renal and Mme de Renal "I absolutely want to take home Sorel, son of the sawmill of planches <...> he will watch the children $\langle\ldots\rangle$ It is a young priest, so good, good Latinist and that will make progress to children "I like enough that they see the sons' children pass. Of Renal, going to the promenade under the guidance of their tutor This will impose. My grandfather often told us that during his youth he had had a tutor/In the garden of MonsieurdeRenal.

4/ Father Sorel and Julien : Well lazy! You will always read your damned books, while you are on guard with the saw? Read them in the evening when you're going to waste your time with the priest./ In the sawmill of the Sorel family.

5/ Mme. De Renal and Julien. "You will not scold them too poorly," said she, after a little silence, and in a voice of which every moment increased, Emotion, you will be good for them, you promise me ".

6/ But is it true, sir, "said she, stopping still, and fearing mortally to be deceived, so much did her belief make her happy," you know Latin? " "Yes, madame," he said, trying to take a cold air; I know Latin as well as $\mathrm{m}$. The cure, and even sometimes he has the goodness to say better than him.

Do not you, the first few days, give the whip to my children, even when they do not know their lessons.

Do not be afraid of Madame, I will obey you in everything /In the courtyard of Madame de Renal's house

6/Narrator "He drew this repugnance from Rousseau's Confessions. It was the only book by which his imagination imagined the world. The collection of the bulletins of the great army and the Memorial of St. Helena completed its Quran "With a soul of fire, Julien had one of those astonishing memories so often united to the sotisse. In order to win the old Cure Chelan, from whom he saw clearly that his future fate depended, He had learned by heart all the new testament in Latin; He also knew the book of the Pope by M. Maistre/At the house of Abbé Célan

7/ Julien, Monsieur de Renal, Madame de Renal, the children of Mrs. De Renal, Eliza, maid, Monsieur Valenaud, "I am here, gentlemen," he said to them, finishing his speech, to teach you Latin . You know what it is like to recite a lesson. Here is the holy Bible, "he said, pointing to a small volume in-32, bound in black. It is especially the story of Our Lord Jesus Christ, which is 
called the New Testament. I will often let you recite lessons, make me recite mine/ At Madame de Renal's

house

8/ Julien and Adolphe "Adolphe, the eldest child, had taken the book. "Open it at random," continued Julian, "and tell me the first word of a paragraph." I will cite by heart the sacred book, the rule of our conduct to all, till you stop"/ at Madame de Renal's house

9/ Narrator Julien and Monsieur de Renal. "In the evening, all Verrieres flocked to M. de Renal to see the marvel. Julien replied to all of them with a gloomy air which kept at a distance. His glory spread so rapidly in the town, that a few days after M. de Renal, fearing that it might be taken away from him, proposed to him to sign a two-year engagement. No, sir, "replied Julien coldly," if you would send me away I should be obliged to go out. " A commitment that binds me without requiring you to anything is not equal, I refuse "Monsieur," said Julien to him, "do you think that, with any other tutor, your children would have made the same progress as with me? If you say no, "continued Julien, without giving M. de Renal time to speak," how dare you reproach me that I neglect them? " <...> Think of the infamy of the words you addressed to me, and of women still In the town of Verrieres,/At the house of Mme de Renal.

\section{B. The corpus of cultural values in the novel Red and Black:}

\section{No./ Characters stated/ Contexts /paes}

1 /Narrator, Madame de Renal, and Julien. "You will have been told," she said without looking at him, "that I am the only heiress of a very rich aunt who lives in Besancon." It fills me with presents ... My sons are making progress ... so amazing ... that I would like to beg you to accept a small present as a mark of my gratitude. It is only a few louis to make you clothes. But ... "she added, blushing even more, and she stopped talkin

Tormented by the idea of Julien's poverty, Mme de Renal spoke to her husband to give him a gift of linen. "My sons are making progress so amazing that I would like to beg you to accept a small present as a mark of my gratitude My sons are making progress ... so amazing ... that I would like to beg you to accept a small present as a mark of gratitude. "It is only a few louis to make you the linen." "What, Madame?" Said Julien. ; It would be useless to speak of this to my husband. - I am small, madam but I am not low <...> that is what you have not reflected. I will be less than a valet if I put myself in the case of hiding from Monsieur de Renal anything relating to my money /At Mme de Renal's house/ 55

2/ Julien and Mme. De Renal "I am small but I am not low" At Madame de Renal's house/55

3/ narrator "Julien was ashamed of his emotion, for the first time in his beloved life; He wept with delight, and went to hide his tears /in the great woods above Verrieres In the forest to the north of the Verrieres/62

4/ Narrator "Instead of those glances charged with delights, which he expected to meet, he found the severe face of Monsieur de Renal, who had arrived two hours before Verrieres, did not hide his discontent with what Julien was passing All morning without taking care of the children/ At Madame de Renal's house/ 72

5/ Narrator, Fouque and Julien But suddenly Julien was happy, he had a reason to refuse. What! I was loose for seven or eight years! I should thus arrive at twenty-eight; But at this age Bonaparte had done his greatest things /at the house of Fouque/ in the valley of the Jura/89 
6/ Narrator Julien announced the plan to become a priest, and was constantly seen in the saw of his father, busied in learning by heart a Latin Bible which the curate had lent him. This good old man, amazed at his progress, spent entire evenings teaching him theology

7/ Julien Sorel Ah! Cried he, "that Napoleon was indeed the man sent from God for the young Frenchmen who will replace him: at sunset, /in the fruit-plantations of the village of Cergy,

8/Narrator "Madame de Renal had been astonished at Julien's words, because the men of his society repeated that Robespierre's return was above all possible because of the young men of the lower classes, too well brought up /at sunset, Fruit plantations of the vilage of Cergy /112

9 /Julien and Mme. De Renal, Alas! I am ten years older than you! How can you love me In the chateau of Monsieur de Renal, in the village of Vergy /107

10/ Monsieur de Renal "I can strike blows at this insolent tutor and drive him away; But bursts in Verrieres and even the whole department /At Madame de Renal's house /141

11 /Monsieur de Renal If I do not kill my wife and dismiss her with ignominy, she has her aunt at Besancon who will give her hand to her hand all her fortune. My wife will go to live with Julien in Paris, and I will still be a dupe /At Mme de Renal's house /142

\section{The corpus containing religious values in the novel Red and Black:}

\section{No. Characters Stated /Context /pages}

1/ Father Sorel, Julien Sorel Answer me without lying, if you can, dog of lizard, where do you know Madame de Renal, when you spoke to her? "I never spoke to her," replied Julian. "I've never seen this lady in church But you will have looked at her, you naughty cheek? Never, you know that at church I only see God, added Julien/ At the house of the Old Sorel/ 35

2 /Narrator; Julien, the cure Chelan. In order to win the old cure Chelan, from whom he saw that his future fate depended, he had learned by Heart all the New Testament in Latin, he also knew the book of the Pope of M. de Maistre. At the house of Mme de Renal and the old priest Chelan /36

3/ Narrator, Julian Suddenly he ceased speaking of Napoleon; He announced the project of becoming a priest, and is constantly seen in the saw of his father, busied in learning by Heart a bible in Latin that the parish had lent him / at the house of the old cure.

4 /Julien Sorel This is the young man of nineteen, but weak in appearance, to whom at most they had given seventeen, who, carrying a small parcel under his arm, entered the magnificent church of Verrieres./ Church of Verrières/ 40

5 /Mme de Renal But in her capacity as heiress, she had been brought up by religious worshipers passing by the sacred Heart of Jesus /City of stained glass windows /53

6/ Madame de Renal, Monsieur de Renal and Stanislas-Xavier "No, listen to me," cried his wife on his knees before him, and trying to hold him back. "Learn the whole truth. I'm the one who kills my son. I gave him life and I take it back. Heaven punishes me, in the eyes of God, I am guilty of murder /At the house of Madame de Renal in the village of Cergy/ 129 
7 /Madame de Renal and Julien Sorel/ "Flee me," she said one day to Julien in the name of God, "leave this house; It's your presence here that kills my son/ At the house of Madame de Renal, at the village of Cergy /129

8/Narrator and Julien Julien remained astonished. This is adultery! Did he think that it would be possible for these priests so foolish to be right? Those who commit so many sins would have the privilege of knowing the true theory of sin? At the house of Madame de Renal, /at the village of Cergy /129

9/ Narrator "Finally heaven had pity on this unhappy mother. Little by little Stanislas-Xavier was no longer in danger/At the house of Madame de Renal, /at the village of Cergy /131

10/ The Bishop of Agde "Never forget, young Christians, that you saw one of the greatest kings of the earth kneel before the servants of this all-powerful and terrible God. These weak, persecuted servants, murdered on earth, as you see by his still bloody wound of St. Clement, they triumph in heaven. Is it not, young Christians, you will remember forever this day? You will hate the ungodly. For ever you will be faithful to this God so great, so terrible, but so good Tuesday, September 3, morning preparing for the welcome of the King of France who will pass/ in the town of Verrieres/ 125

11/ The bishop of Agde, and the young girls - You promise? By advancing the arm with an air inspires We promise, said the young girls, melting into tears Tuesday, September 3, morning in preparation for the welcome of the King of France who will spend/ in the town of Verrieres /125

\section{Corpus containing historical educational values in the novel La Chartreuse de Parme:}

No./ Characters set/ context/ pages

1/ Fabrice Del Dongo "I'm leaving," he said. I will join the Emperor, who is also King of Italy "To the castle of the Marquise Del Dongo./44

2/ Fabrice Del Dongo: I will offer to this great man very little, but finally all that I can offer, the help of my weak arm /At the castle of the Marquise Del Dongo /45

3/ Fabrice Del Dongo The amount of blood he lost from the whole romantic part of his character At the castle of the Marquise Del Dongo

4/ Letnan Robert, "On May 11, 1796, General Bonaparte made his entry into Milan at the head of this young army which had just passed the bridge of Lodi The city of Milano in 1796/ 21

5/ French Soldier "In Italy in 1796, the same day, a notice of a contribution of six million war was posted, struck for the needs of the French army, which, having just won six battles and conquered twenty provinces Lacked only shoes, pants, clothes and hats /The city of Milano in 1796/23

6 /Narrator, soldier: Lieutenant Robert. "The pretty madness, the gaiety, the voluptuousness, the forgetfulness of all sad, or only reasonable sentiments, were carried to such a point, since May 15, 1796, that the French entered Milan until April 1799, They were expelled from it after the battle of Cassano, which has been cited as old merchant millionaires, old usurers, and old notaries, who during this interval had forgotten to be morose, money. 
The Marquise del Dongo, upset to see so much gaiety, had been one of the first to regain his magnificent castle of Grianta, beyond Como, where the ladies led Lieutenant Robert. This castle, situated in a position perhaps unique in the world, on a plateau fifty feet above the sublime lake of which it dominates a great part, had been a fortified place. "/The city of Milano in 1796 /26- 27

7/Fabrice, La Vivandiere, Hussard, Leutenant Robert It was a long time since Fabice no longer saw the earth Flying in black crumbs under the action of the bullets In the prison /64

8/Lieutenant Robert The general they followed was tall, thin, and had a dry face and a terrible eye. "This general was none other than Count d'A, Lieutenant Robert of May 15, 1796. What happiness he had found to see Fabrice del Dongo In battlefields /64

9/ Fabrice del Dongo All this adventure had not lasted a minute, the wounds of fabrice were nothing. They tightened the arms of the bands cut in Colonel's shirt The battle in the Waterloo zone 185

10/ Fabrice.del Dongo "What did he see, was it a battle? And in the second place, was this battle Waterloo?" The Battle in the Waterloo Zone /89

11/ Fabrice del Dongo, Gina del Dongo, Count Mosca della Rovere Sorezana "the enthusiasm for Napoleon, to the point of joining him to Waterloo? Think of what we would all be if Napoleon had vanquished at Waterloo. " Situation of the battle of waterloo/129

12/ Laurent, Gouvion-Saint-Cyr "It's because I did not steal anything in this Spain, and you have to live. I was mad with glory; A flattering word from the French general, Gouvion-Saint-Cyr, who commanded us, was then everything for me. At the fall of Napoleon, it happened that while I was eating my good at my service, my father, a man of imagination, and who saw me as a general, built me a palace in Parma. In 1813, I found myself for all well a great palace to finish and a pension Situation of the battle of waterloo/107

\section{E. Data on the social status of the author}

\section{No./ Places Events /Date}

1 (a). Henry Beyle, known as Stendhal, is born

(B). The death of his mother Henriette Gagnon, during her sixth pregnancy, surely because of a medical error. Stendhal conceived an immense despair, which was in no way calmed by a sermon from Abbe Rey, close to the family who proclaimed to console him: "Stendhal will keep a deep wound and a great hostility towards religion and its false consolations.

(C). 23 Nov 1835 stendhal begins the writing of life Henri Brulard symbolically testifying to the repercussions of this event; The subtitual mothers sought by two Stendhalian heroes, Madame de Renal for Julien Sorel and Gina Pietranera for Fabrice del Dongo. Grenoble/1835

$2 /(a)$. It is generally reticent that he was brilliant in mathematics, that it was especially his grandfather who brought him affection and education.

(b). The life of Stendhal marked by revolt and rebelliousness towards his father, especially his preceptors, and the monarchical political authorities 
(c). He will keep a particularly distressing memory of his preceptor Abbé Raillane, a memory he finds in the episode of the Seminar in the Red and the Black

(d). It was at Uncle Romain Gagnon, on the Ladders, that Stendhal knew his first happiness as a reader/Grenoble

3 /He had little affinity with His father Grenoble His childhood/ http://www.etudes-litteraires.com/

4/ (a). Sent to Paris to join the Ecole Polytechnique./ Paris/1800/ http://www.etudes-litteraires.com/

(b). He who can not stand the indiscriminate mass of this people whom he considers uneducated/grenoble/1800/

(c). Thanks to his grandfather who was appointed to the central jury of public instruction of the Isère and can have Henri admitted to the central school of Grenoble/ Panorama of the author, Stendhal, Paris, Studyrama, 2003, p 12

(d). He studied science, including mathematics in which he distinguished himself, as well as literature, logic and grammar/ Panorama of the author, Stendhal, Paris, Studyrama, 2003, p 12

5/ He obtains a post at the Ministry of War Paris 1800/ Panorama of the author, Stendhal, Paris, Studyrama, 2003/ p.3

$6 /$ He accompanies Bonaparte in Italy, attends the battle Marengo, Italy 1800-1802 // Panorama of the author, Stendhal, Paris, Studyrama, 2003/ p.3

7/He leaves the army, travels Italy 1802 / / Panorama of the author, Stendhal, Paris, Studyrama, $2003 /$ p.3

8/ It resumes of service and becoming auditor at the council of State Paris and abroad 1806 http://www.etudes-litteraires.com/

9/ It is named to Civita-Vecchia Civita-Vecchia 1831 The Charterhouse of Parma

10/ Release of the novel Le Rouge et le Noir Paris 1830 La Chartreuse de Parme

11/ The publication of the novel The Chartreuse of Parma Paris 1938 In easy French: /the Chatreuse of Parma

12 /Stendhal draws inspiration from some of these historical episodes to create the atmosphere in which/ the Chartreuse de Parme

13/ Stendhal is a revolt who, throughout his life, severely criticizes the way of life of people of his time/

14 /His taste for adventure is such that, very young, he does not hesitate to follow Napoleon in Italy

15/ Berthet affair, this is a resounding process which was held at the assizes of Isère in December 1827. A former seminarian of very modest extraction, Antoine Berthet, had, in full mass, in the church of Brangues en Dauphiné, shot Mrs. Michoud de la Tour, wife of the mayor, to whom he had been a tutor. Questioned by his motives, he had declared that his act was the result of an outburst of resentment and jealousy: loved by Mrs. Michoud/ Grenoble/1827 Jean Prévost, The Berthet Affair, Historical Account,/ La Thebaïde, Paris, 2014, pages. 7-8 
16 /The lamentable destiny of antoine Berthet, a young suffering home, poor and superiorly gifted, unloved, tormented, ambitious, finding a tragic conclusion in the form of apotheosis on the scaffold of the Place de Grenette in Grenoble, That is to say under the very windows in which Hennri Beyle had often leaned in his grandfather's apartment, could not but attract the attention of Stendhal. The debates of this special process were transcribed in detail In several deliveries of the Gazette des tribunaux, which included Stendhal/Grenoble/1837Jean Prévost, The Berthet Affair, Historical Account, /La Thebaïde, Paris, 2014, p.8

He has declared that he finds there as a writer a veritable mine of new insights into what human nature is capable of when passion drives it into its ultimate entrenchments./Grenoble/1827/Jean Prévost, The Berthet Affair, Historical Account, La Thebaïde, Paris, 2014, p.8

He has declared that he finds there as a writer a veritable mine of new insights into what human nature is capable of when passion drives it into its ultimate entrenchments./Grenoble/1827/Jean Prévost, The Berthet Affair, Historical Account, La Thebaïde, Paris, 2014, p.8

18 So it would be the famous Berthet case that would be the origin of Rouge et le Noir, published two years later. As usual, Stendhal blurred the tracks. In his novel, he situates the trial and execution of Julien Sorel (who shot in the church of Verrieres on his mistress, Madame de Renal, because she denounced him as intriguing on the very eve of a Brilliant marriage with the most coveted heiress of the Parisian aristocracy) in Besançon, where he specifies never to have set foot /Jean Prévost, The Berthet affair, historical account, La Thebaïde, Paris, 2014, p.9

\section{F. Data on the views of writers}

\section{No. /Events Locations /Moments/ Sources}

1 (a). Henry Beyle, known as Stendhal, is born/ Grenoble/1783/ La Chatreuse of Parma, brigette Faucard-Martinez, Clé International, 1996, p. 3

(b). The death of his mother Henriette Gagnon, during her sixth pregnancy, surely because of a medical error. Stendhal conceived an immense despair, which was in no way calmed by a sermon from Abbe Rey, close to the family, who proclaimed to comfort him: "Stendhal will keep a deep wound and a great hostility towards religion and his false consolations./ 23 Nov 1790/Grenoble/ Panorama of the author, Stendhal, Paris, Studyrama, 2003, p 11

(c). 23 Nov 1835 stendhal begins the writing of life Henri Brulard symbolically testifying to the repercussions of this event; The subtitual mothers sought by the two Stendhalian heroes, Madame de Renal for Julien Sorel and Gina Pietranera for Fabrice del Dongo. /Paris/ Panorama of the author, Stendhal, Paris, Studyrama, 2003, p 11

$2 /(a)$. It is generally reticent that he was brilliant in mathematics, that it was especially his grandfather who brought him affection and education.

(b). Stendhal's life marked by revolt and rebelliousness towards his father, especially his preceptors, and the monarchical political authorities

(c). He will keep a particularly distressing memory of his preceptor Abbé Raillane, a memory he finds in the episode of the Seminar in the Red and the Black

(d). It was at Uncle Romain Gagnon, on the Scales, that Stendhal knew his first happiness as a reader

3 /He had little affinity with His father/Grenoble/ His childhood/http://www.etudes-litteraires.com/ 4 (a). Sent to Paris to enter Polytechnique./Paris/1800/ http://www.etudes-litteraires.com/ 
(b). He who can not stand the indiscriminate mass of this people whom he considers uneducated

(c). Thanks to his grandfather who was appointed to the central jury of public instruction of the Isère and can have Henri admitted to the central school of Grenoble/1796/panorama de l'auteur, Stendhal, Paris, Studyrama, 2003, p 12

(d). He studied science, including mathematics in which he distinguished himself, as well as literature, logic and grammar/Paris/ panorama de l'auteur, Stendhal, Paris, Studyrama, 2003, p 12

5/ He Gets a Post at the War Ministry /Paris /1800 / panorama de l'auteur, Stendhal, Paris, Studyrama, 2003, p 12

$6 / \mathrm{He}$ accompanies Bonaparte in Italy, attends the battle Marengo, /Italy /1800-1802/

7/ He leaves the army, travels/ Italy /1802 / panorama de l'auteur, Stendhal, Paris, Studyrama, 2003, $\mathrm{p} 12$

8/ He resumes service and becomes auditor at the State Council/ Paris and abroad /1806 http://www.etudes-litteraires.com/

9/ It is named to Civita-Vecchia Civita-Vecchia/ 1831/The Charterhouse of Parma

10/ Release of the novel Le Rouge et le Noir/ Paris/ 1830/ La Chartreuse de Parme

11/ The publication of the novel The Chartreuse of Parma/ Paris/ 1938/ In easy French: the Charterhouse of Parma

12 /Stendhal draws inspiration from some of these historical episodes to create the atmosphere in which the Chartreuse de Parme/In French easy: the Charterhouse of Parma

13/ Stendhal is a revolt who, throughout his life, criticizes harshly the way of life of the people of his time In easy French: the Charterhouse of Parma

14/ His taste for adventure is such that, very young, he does not hesitate to follow Napoleon in Italy In easy French: the Charterhouse of Parma

15/ Berthet affair, this is a resounding process which was held at the assizes of Isère in December 1827. A former seminarian of very modest extraction, Antoine Berthe, had, in full mass, in the church of Brangues en Dauphiné, shot Mrs. Michoud de la Tour, wife of the mayor, to whom he had been a tutor. Questioned by his motives, he declared that his act was the result of an outburst of resentment and jealousy: loved by Mrs. Michoud/Grenoble/1827 Jean Prévost, The Berthet Affair, Historical Account, La Thebaïde, Paris, 2014, pp. 7-8

16/ The lamentable destiny of Antoine Berthet, a suffering young man, poor and superiorly gifted, ill-loved, tormented, ambitious, finding a tragic conclusion in the form of apotheosis on the scaffold of the Place de Grenette in Grenoble, That is to say under the very windows where Hennri Beyle had often leaned in his grandfather's apartment, could not but attract the attention of Stendhal. The debates of this special process were transcribed in Detail in several deliveries of the Gazette des tribunaux, which included Stendhal/Grenoble/1837/Jean Prévost, The Berthet Affair, Historical Account, La Thebaïde, Paris, 2014, p.8

17/ He has declared that he finds there as a writer a veritable mine of new insights into what human nature is capable of when passion drives it into its ultimate entrenchments./Grenoble/1827/Jean Prévost, The Berthet Affair, Historical Account, La Thebaïde, Paris, 2014, p.8

18 /So it would be the famous Berthet case that would be the origin of Rouge et le Noir, published two years later. As usual, Stendhal blurred the tracks. In his novel, he situates the trial and execution of Julien Sorel (who shot in the church of Verrieres on his mistress, Madame de Renal, because she denounced him as intriguing on the very eve of a Brilliant marriage with the most 
coveted heiress of the Parisian aristocracy) in Besançon, where he says never to have set foot /Jean Prévost, The Berthet affair, historical account, La Thebaïde, Paris, 2014, p.9

\section{G. Data on the views of writers}

\section{No./ Events Locations /Moments /Sources}

1. a). Henry Beyle, known as Stendhal, is born/Grenoble/1783/La Chatreuse of Parma, brigette,Faucard-Martinez,CléInternational,1996,p.3

b). The death of his mother Henriette Gagnon, during her sixth pregnancy, surely because of a medical error. Stendhal conceived an immense despair, which was in no way calmed by a sermon from Abbe Rey, close to the family, who proclaimed to comfort him: "Stendhal will keep a deep wound and a great hostility towards religion and his false consolations./Grenoble/ 23 Nov 1790/ Panorama of the author, Stendhal, Paris, Studyrama,2003,p11

c). 23 Nov 1835 stendhal begins the writing of life Henri Brulard symbolically testifying to the repercussions of this event; The subtitual mothers sought by the two Stendhalian heroes, Madame de Renal for Julien Sorel and Gina Pietranera for Fabrice del Dongo. Grenoble/Paris/1835/Panorama of the author, Stendhal, Paris, Studyrama, 2003, p 11

2. (a). It is generally reticent that he was brilliant in mathematics, that it was especially his grandfather who brought him affection and education./Grenoble/ son enfance/His youth http://www.etudes-litteraires.com/

(B). Stendhal's life marked by revolt and rebelliousness towards his father, especially his preceptors, and the monarchical political authorities/ Grenoble/ His youth/ Panorama of the author, Stendhal, Paris, Studyrama, 2003, p 11

(C). He will keep a particularly distressing memory of his tutor, Abbé Raillane, a memory he finds in the episode of the Seminar in the Red and the Black/ Grenoble/ At Les Echelles/ His youth/ Panorama of the author, Stendhal, Paris, Studyrama, 2003, p 12

(D). It is at Uncle Romain Gagnon, on the Ladders, that Stendhal will know his first reader pleasures/ His youth/ Panorama of the author, Stendhal, Paris, Studyrama, 2003, p 12

3 / He had little affinity with His father/ Grenoble /His childhood/ http://www.etudes-litteraires.com 4/ (a). Sent to Paris to enter Polytechnique./Paris/1800/ http://www.etudes-litteraires.com

b). He who can not stand the indiscriminate mass of this people whom he considers uneducated/ http://www.etudes-litteraires.com

c). Thanks to his grandfather who was appointed to the central jury of public instruction of the Isère and can have Henri admitted to the central school of Grenoble/Grenoble/1796/ Panorama of the author, Stendhal, Paris, Studyrama, 2003, p 12

d). He studied science, including mathematics in which he distinguished himself, as well as literature, logic and grammar/Grenoble/1798 /Panorama of the author, Stendhal ,Paris, Studyrama, 2003, p 12

5 /He Gets a Post at the War Ministry/ Paris/ 1800 / Panorama of the author, Stendhal ,Paris, Studyrama, 2003, p 3

6/ He accompanies Bonaparte in Italy, attends the battle Marengo, Italy 1800-1802/ Panorama of the author, Stendhal ,Paris, Studyrama, 2003, p 3 
7/ He leaves the army, travels/ Italy /1802 / Panorama of the author, Stendhal ,Paris, Studyrama, 2003, p 3

8/ He resumes service and becomes auditor at the State Council/ Paris and abroad /1806/ http://www.etudes-litteraires.com/

9/ He is named to Civita-Vecchia Civita-Vecchia/ 1831/ The Charterhouse of Parma

10/ The publication of the novel Le Rouge et le Noir /Paris/ 1830/ La Chartreuse de Parme

11/ The publication of the novel The Chartreuse of Parma Paris /1938 /In easy French: the Charterhouse of Parma.

12/ Stendhal draws inspiration from some of these historical episodes to create the atmosphere in which the Chartreuse de Parme/In French easy: the Charterhouse of Parma

13/ Stendhal is a revolt who, throughout his life, criticizes harshly the way of life of the people of his time /In easy French: the Charterhouse of Parma

14/ His taste for adventure is such that, very young, he does not hesitate to follow Napoleon in Italy In easy French: the Charterhouse of Parma

$15 /$ Berthet affair, this is a resounding process which was held at the assizes of Isère in December 1827. A former seminarian of very modest extraction, Antoine Berthet, had, in full mass, in the church of Brangues en Dauphiné, shot Mrs. Michoud de la Tour, wife of the mayor, to whom he had been a tutor. Questioned by his motives, he declared that his act was the result of an outburst of resentment and jealousy: loved by Mrs. Michoud/Grenoble/1827/Jean Prévost, The Berthet Affair, Historical Account, La Thebaïde, Paris, 2014,pp.7-8

16/ The lamentable destiny of Antoine Berthet, a suffering young man, poor and superiorly gifted, ill-loved, tormented, ambitious, finding a tragic conclusion in the form of apotheosis on the scaffold of the Place de Grenette in Grenoble, That is to say under the very windows where Henri Beyle had often leaned in his grandfather's apartment, could not but attract the attention of Stendhal. The debates of this special process were transcribed in Detail in several deliveries of the Gazette des tribunaux, which included Stendhal/Grenoble /1837/Jean Prévost, The Berthet Affair, Historical Account, La Thebaïde, Paris, 2014, p.8

$17 / \mathrm{He}$ has declared that he finds there as a writer a veritable mine of new insights into what human nature is capable of when passion drives it into its ultimate entrenchments. /Grenoble//1827/ Jean Prévost, The Berthet Affair, Historical Account, La Thebaïde, Paris, 2014, p.8

18/ So it would be the famous Berthet case that would be the origin of Rouge et le Noir, published two years later. As usual, Stendhal blurred the tracks. In his novel, he situates the trial and execution of Julien Sorel (who shot in the church of Verrieres on his mistress, Madame de Renal, because she denounced him as intriguing on the very eve of a Brilliant marriage with the most coveted heiress of the Parisian aristocracy) in Besançon, where he says he never put his feet/ Jean Prévost, L'affaire Berthet, recit historique, La Thébaïde, Paris,2014, p.9

\section{RESULTS AND DISCUSSION}

The results obtained concerning the structural description, the description of educational values which are intellectual and cultural: religious. The raising of the value of education in the novel is done in two ways, namely explicit and implicit. The educational values exist in novels are religious, intellectual and cultural. The Mode of Expression is through the male role: Julien Sorel 
who is used to reading, Latin and religion study, who come from a poor family, who becomes preceptor: teacher tutoring in a ruling family, Rich, noble and educated.

The data of Stendhal's life are reflected in these novels: He loves to study, he does not love his father, he is in search of the tenderness of a mother, he had cold tutors during his childhood and his adolescence. He has made trips and stays in Italy. He was engaged in the Napoleonic army, he adored the Emperor, he worked in the state administration. He worked as a journalist, he read a lot, he was familiar with the Berthet affair, telling almost the same story as Julien Sorel. Finally he who criticized the social classes of the nineteenth century. All this is shown in the two novels: The Red and the Black and The Charterhouse of Parma.Words like: books, the Memorial of St. Helena, the collection of the bulletins of the great army; Preceptor, know by heart the Bible, know to speak Latin show us intellectual and educational values. These words carry an important message, that is, a message concerning education. And we know that towards the end of the nineteenth century the government declared that the school was compulsory and free. The law of 1870 was inspired, among other things, by the works of the writers and among them is Stendhal.

The religious elements are indicated among others by the following words: the priest, the abbot, the church, the mass, the new testament, sin, God, forgiveness. In the nineteenth century people were still very religious and believers.

The religious elements are indicated among others by the following words: the priest, the abbot, the church, the mass, the new testament, sin, God, forgiveness. In the nineteenth century people were still very religious and believers.

The historical aspects are evoked by date, war, waterloo, general, captain, soldier, canon etc. Historical values are clearly highlighted in the novel Chartreuse de Parme. Cultural expressions can be found in events or in utterances: I would like to beg you to accept a small present as a mark of my gratitude; I am small but I am not low etc. The results obtained relating to the structural description, the description of educational values that are intellectual and cultural religious

The revelation of the value of education in the novel is made in two ways, that is, explicit and implicit. The educational values exist in the novels are religious intellectual and cultural. The Mode of Expression is through the male role: Julien Sorel who is used to reading, Latin and religion study, who come from a poor family, who becomes tutoring teacher in a ruling, rich, Noble and educated. Although the religious value indicated by the heroine: Madame de Renal clearly through her cultural discourse seen in the actions of some of the characters in the novel.

The values of education that have been overshadowed by the family of economic activity, the rich ruling family life and the religious life seem very important in this novel. Of course, in this novel, the tragedy in the novel occurs due to feelings of love that appear on the three main characters namely Julien Sorel, Madame de Renal and Mathilde de la Mole. Whereas the political problems revealed by the personage include: Monsieur de Renal as mayor of Verrieres, Count de La Mole, a high-ranking high official of the State, who works at Paris.

The novel La Chartreuse de Parme is narrated using the technique in the third person (the narrator) that the author is free to say what they saw, known ... and experienced. The educational values presented by Fabrice del Dongo, a young Italian nobleman, was a strong supporter of Napoleon. Although full of limitations, he managed to reach the battle of Waterloo, but he was not directly involved in the fighting. Being rejected by his father, a supporter of the monarchy, Fabrice has traded his military career in the clergy of the church and became Archbishop coadjutant de Parme.

From the data analyzed, it is found that Roman The Red and the Black and the Carthusian Monastery has the same structure. The narration flow is dominated by a chronological flow. The 
representation of the characters of the main characters Julien Sorel and Fabrice del Dongo, reflecting the life of Stendhal, in the second novel in general, dramatically and analysis. These two figures show courage in the face of events they are going through. But Julien Sorel showed more courage to accept heavy penalties to do what he did. While Fabrice del Dongo happier because he was more patient and willing.

The context is the place of the events of the history in the novel The Red and the Black took place in Verrières, Besançon and Paris, while the background of the scene in the novel The Chartreuse of Parma took place in Parma, France and Belgium. The context represented is clearly the background time of the year of the life of Stendhal who lived in the places mentioned in the two novels.

From a genetic stucturalist point of view, the themes were presented both by the novel and is the theme of human life that express the values of intellectual, cultural, religious education and find educational values described in an explicit and implicit manner and Is associated with the background of socio-cultural and political events and the economic state of France XIX century. The mastery of language can push a person of the poor class to enter the world of intellectual social policy. Similarly, courage and heroism can lift a person into a person who is valued in the community. The courage to defend truth and heroism increases the value of education with in society.

Therefore It is recommended to still study the two Romans above both in the academic and intellectual environment in the wider sense for the educational values found in the novel that could help in the formation of a factor of young generation.

\section{REFERENCES}

Albert, Marie-Claude, Souchon, Marc, Les textes littéraires en classe de Langue, Paris : Hachette, 2000

Blin, Georges, Stendhal et les problèmes de la personnalité, Paris: José Corti. 2001

Bourdenet, Xavier, Lectures de Stendhal, Le Rouge et Le Noir, Rennes: Presses Universitaires de Rennes, 2013

De Biasi, Pierre-Marc, Génétique des textes, Paris : Biblis, 2011.

Djojosuroto, Kinayati, Trijanto, Endang K, Metodologi Penelitian Il- Imiah sebagai Dasar Penelitian Bahasa dan Sastra, Yogyakarta: Penerbit Graha Cendekia, 2010

Elippses, , Analyses \& Rélexions sur Stendhal, Lucien Leuwen, Paris: éditions de Marketing S.A, 1995.

Evrard, Franck, , Analyses \& Réflexions sur Stendhal, La Chartreuse de Parme, Paris: Ellipes, 2000

Goldmann Lucien, structuralisme génétique et création littéraire, Paris Gonthier, 1976

Golmann, Lucien, Towards a Sociology of the Novel, Tavistock Publications, London, 1978

Prévost, Jean, L'affaire Berthet, le fait Divers qui a inspire Le Rouge et le Noir, Paris: La Thébaïde , 2014.

Stendhal, Le Rouge et Le Noir, Paris: Librairie Jules Tallandier, 1977

Stendhal, La Chartreuse de Parme, Paris: Gallimard, 1972. 